\title{
Achievement of Sustainable Development Goals In Indonesia: Quadruple Helix Model
}

\author{
Agustina Suparyati \\ \{agustina_suparyati@trisakti.ac.id\} \\ Faculty of Economics and Business, Trisakti University, Jakarta
}

\begin{abstract}
This study has two objectives, namely measuring the sustainable development index (SDI) and analyzing the role of development actors using the Quadruple Helix model which is a collaborative concept with networks that connect academics, government, industry, and society, each of which will run according to its function in development based on the common interest. SDI is a composite index of HDI which is a combination of economic and social pillars, EQI to measure the Environmental pillar and IDI is an indicator for the pillars of governance and law in Indonesia. The government's role in the SDGs is in accordance with its function as an allocator, distributor and stabilizer as measured by the variables of the Regional Government Expenditure Ratio to GRDP, the Ratio of Regional Taxes to GRDP, the level of inflation, and the effectiveness of regional finance, while the private sector's role is measured by the size of Private Investment, Banking Credit and Per Capita Consumption Expenditure. The role of universities in achieving the SDGs is indicated by the large gross enrollment rate (GER) of universities and community indicators in society measured by the performance of micro and small businesses. The estimation method used is panel data analysis with a coverage area of 33 provinces in 2016-2020. The estimation results show that bank credit, the performance of Micro and Small Enterprises and the Gross Enrollment Rate (GER) of universities have a positive and significant influence on SDI.
\end{abstract}

Keywords: Sustainable Development Goals (SDGs); Quadruple Helix; Role of Government; Innovation

\section{Introduction}

National development aims to achieve sustainable and inclusive economic growth, namely growth that meets the needs of the current generation without compromising the ability of future generations, is distributed in various regions, and can reduce income inequality. Sustainable development is a necessary condition for the success of a country; however, it is not enough if it is not followed by inclusive development. Inclusive development is defined as growth that not only creates new economic opportunities, but also ensures equal accessibility to opportunities created for all segments of society, especially for the poor. In the United Nations Conference (UN) held in Rio de Janeiro (Brazil) in June 2012 a sustainable development agenda called the Sustainable Development Goals (SDGs) was discussed which 
is a set of goals, targets, and indicators of sustainable development that are universal. The SDGs are a continuation and expansion of the Millennium Development Goals (MDGs) that have been carried out by countries from 2001 to the end of 2015. At a high-level meeting at the UN headquarters in September 2015, 193 UN member countries agreed to make the SDGs a framework for the development agenda and political policies for the next 15 years from 2016 to 2030. The SDGs as a result of the declaration contain 17 goals that can be grouped into 4 pillars that are inseparable and interdependent. These four pillars are to show the existence and importance of balance between the 3 (three) main pillars, namely the pillars of social development, the pillars of economic development, environmental development and supported by the 4th (fourth) pillar, namely the pillars of governance, global partnership and law.

Basically sustainable development is often a difficult concept to understand (elusive), although it has become a development jargon throughout the world [1], however, there is still no definite measure of the level of sustainability of a development, so the big question is how establish a measure of sustainable development that is more representative of the conditions of sustainable and inclusive development. Several studies have attempted to measure the sustainable development index with various variables and various indexation methods, including Nourry, M. [2], and Kondyli, J. [3], Hatthachan Phimpanthavong [4], while in the case of Indonesia, some have done this. research including Akhmad Fauzi, Alex Oxtavianus [1], Bappenas [5] and Wibowo [6]. In 2016, the Bertelsmann Stiftung and Sustainable Development Solutions Network (SDSN) based in New York published the SDG Index and Dashboards: Global Report, which contains the methodology used to measure the SGD index for the scope of the country. In 2016, the results of the SDG Index measurement obtained information that out of 147 countries observed, Indonesia was ranked 83, Malaysia ranked 59, Singapore ranked 31, Thailand ranked 62 and the Philippines ranked 91. The country that ranks 1st for its sustainable development index is Sweden. In this study the measurement of the sustainable development index (SDI) using a composite of the indicators of the Human Development Index (HDI), Environmental Quality Index (EQI) and the Indonesian Democracy Index (IDI) and then mapping the results of the SDGs in 33 provinces in Indonesia for the period $2016-2019$.

In essence, success in implementing the Sustainable Development Goals or SDGs is a "movement" that involves all parties in the economy to synergize according to their roles, functions and abilities. The direction and orientation of national development are always pursued and realized so that the results can be truly felt by all Indonesian people. For this purpose, national development needs to be implemented in a programmed, directed, systematic, and sustainable manner in a national management system (sismennas) that can run effectively and efficiently. The role of all development actors is substantive in achieving national goals. The classification of stakeholders in national development is categorized into various concepts, one of which is the triple helix plus society model (Academic, Business, Government, and Society, ABG-S), referred to as the quadruple helix which is the concept of collaborative collaboration with networks that connect academics. , government, business, and society are based on common interests. In the quadruple helix concept, universities (academics) are centers of scientific development that have human and scientific resources capable of generating new ideas through a series of systematic analysis and research as producers and users of innovation. Business people are business actors, investors, technology creators, job creators whose role is to change economic potential into something (product or service) that has economic value, they are producers, drivers, and users of innovation results. The government (government) has a function as a regulator that makes policies to create a good business atmosphere; the government acts as a catalyst that encourages creativity and 
innovation in business products so that they can work towards a higher degree of competition, on the other hand the government can function as a producer and user of innovation results, while society (society) is a community that receives product/service services. given by the ABG element.

In this study, the role of the government, society, academics and the private sector on the sustainable development index is represented by variables such as local government spending, the ratio of local taxes to GRDP (Tax Ratio), inflation, and the level of effectiveness of regional financial management. the role of the government, while for the private sector it is measured by the amount of bank credit per province and the amount of private investment, then the performance of Micro and Small Enterprises (SMEs) to represent the behavior of the community in society with a productive workforce and the variable Gross Enrollment Rate (GER) of higher education is variable used to measure the role of academics as providers of quality human resources.

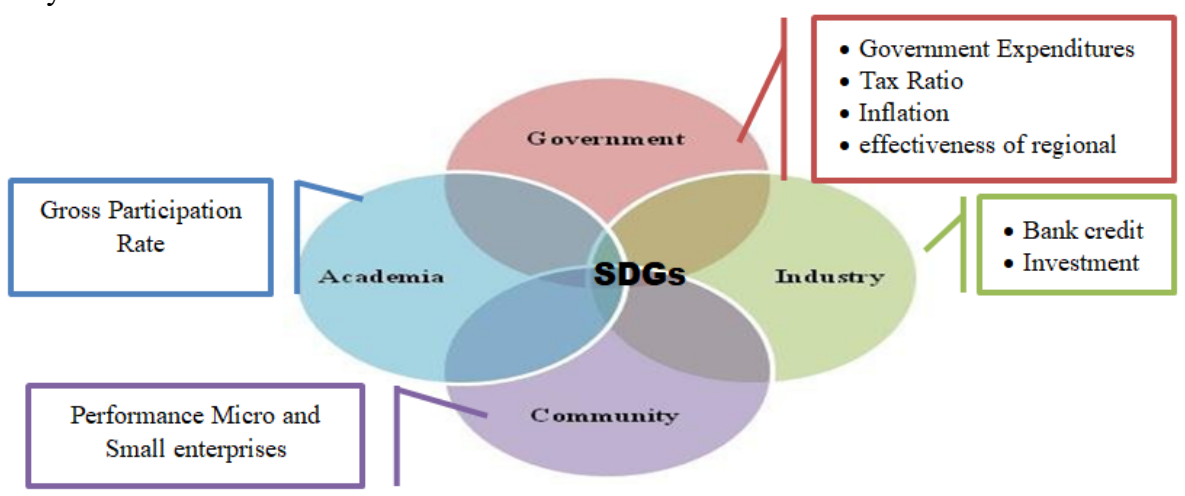

Fig. 1. Model Quadruple Helix for Sustainable Development

\section{Research Methodology}

\subsection{Method for Compiling the Sustainable Development Index}

Sustainable development is often described as not only an improvement in economic and social development, but also described as an improvement in the quality of life that is adjusted to a guaranteed environmental carrying capacity, also supported by good governance. Based on this argument, the scenario for measuring the composite index of sustainable development is based on a combination of relevant indicators representing the four development pillars of the SDGs 


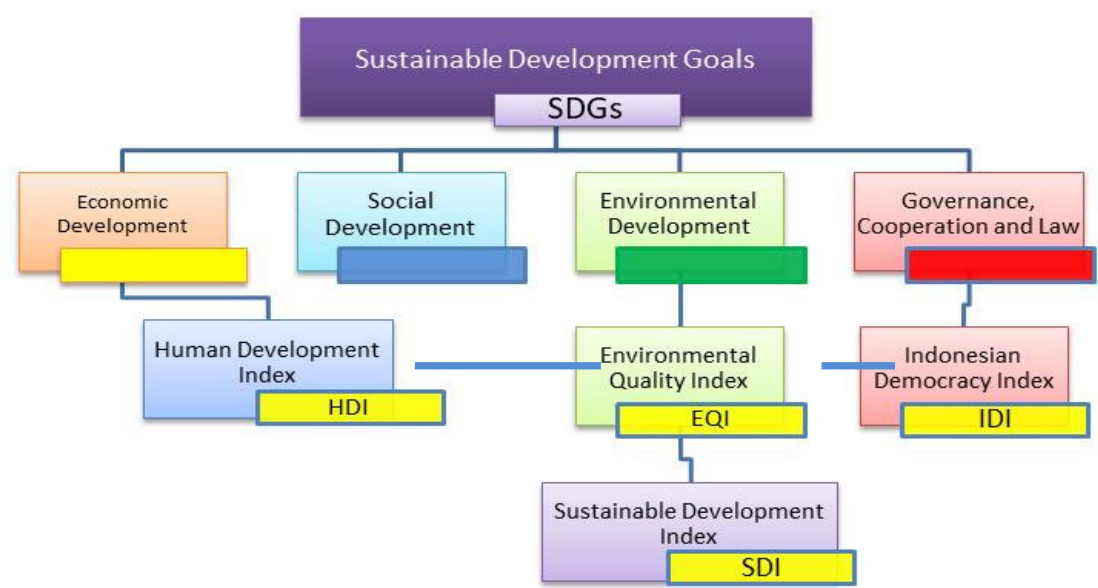

Fig. 2. Preparation of Sustainable Development

The pillars of economic and social development are measured by the Human Development Index (HDI) which is a measure of life expectancy, literacy, education and living standards, the pillars of environmental development are used the Environmental Quality Index (EQI) which describes the condition of Indonesia's environment, which is focused on environmental media. water, air and land cover, and indicators of governance and law are the Indonesian Democracy Index (IDI) which is a composite indicator that shows the level of development of democracy in Indonesia whose level of achievement is measured based on the implementation and development of 3 aspects, namely aspects of civil liberties, human rights. political rights and aspects of democratic institutions. After all the compiling indicators have been standardized, the next step in calculating the sustainable development index is to determine the weight of each indicator. In this study the weighting of indicators is carried out in the most moderate way, namely giving the largest weight to the HDI of $40 \%$ because it is a combination of the pillars of economic and social development, while EQI and IDI are each given a weight of $30 \%$, each representing the pillars of environmental and social development. governance, cooperation and law so that the formula for calculating SDI is as follows:

$S D I=\frac{(4 x H D I)+(3 x E Q I)+(3 x I D I)}{10} \times 100$

The results of this Sustainable Development Index (SDI) will then become the dependent variable in the data equation model with the independent variable representing the role of the sustainable development actors in accordance with the Quadruple Helix model consisting of academics, government, business, and society based on common interests.

\subsection{Panel Data Analysis Method}

The econometric analysis technique used in this study is a panel data model with the following equation model:

$$
\begin{aligned}
\mathrm{SDI}_{\mathrm{it}}= & \alpha+\beta_{1} \cdot \mathrm{GOVE}_{\mathrm{it}}+\beta_{2} \cdot \mathrm{TR}_{\mathrm{it}}+\beta_{3} \cdot \mathrm{INF}_{\mathrm{it}}+\beta_{4} \cdot \mathrm{EF}_{\mathrm{it}}+\beta_{5} \cdot \mathrm{CREDIT}_{\mathrm{it}}+ \\
& \beta_{6} \cdot \mathrm{INV}_{\mathrm{it}}+\beta_{7} \cdot \mathrm{SMEs}_{\mathrm{it}}+\beta_{8} \cdot \mathrm{GER}_{\mathrm{it}}+\varepsilon_{\mathrm{it}}
\end{aligned}
$$




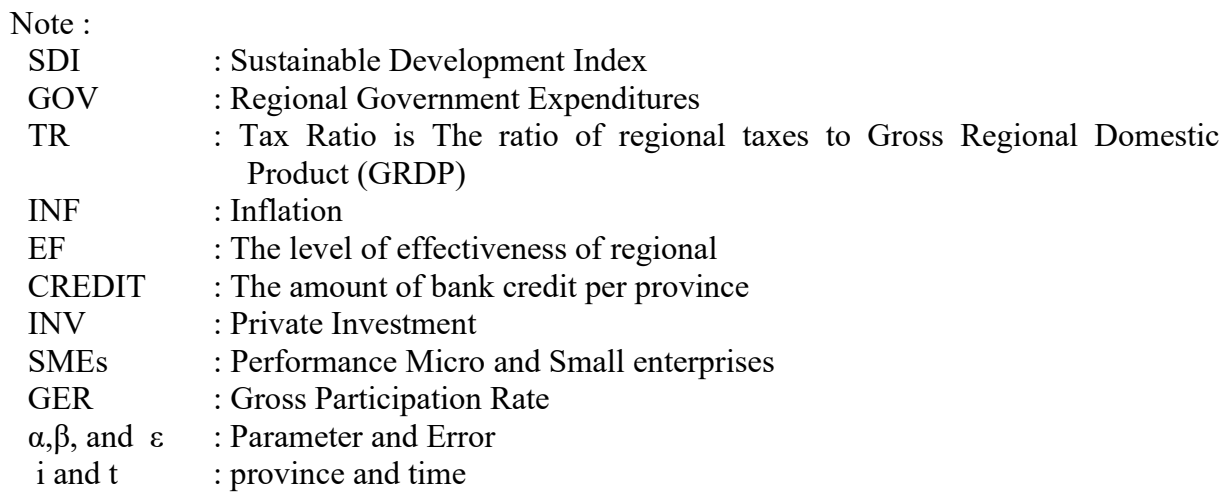

In estimating the panel regression model, there are three approaches that are often used, including the common effect model, the fixed effect model, and the random effect model.

a. Common Effect Model (CEM) is the simplest estimate with the assumption that between time and between individuals are the same (not different) in regression estimation

b. Fixed Effect Model (FEM) is one of the regression estimates which assumes that the slope and intercept are the same (not different) in the panel data.

c. Random Effect Model (REM) is one of the regression estimates that takes into account the degrees of freedom with the assumption that there is an error relationship between time or this year's error.

The three regression estimation models above can only be used to estimate if they have passed the model test to get the best model, including:

a. The Chow test (F-Test) is one of the tests that serves to select the appropriate regression estimation model between the CEM and FEM models.

b. Hausman Test (Hausman Test) is one of the tests conducted to choose between FEM and REM.

c. The LM (Langrange Multiplier) test is one of the tests carried out in order to be able to choose between REM and CEM regression estimates.

\section{Results and Discussion}

\subsection{Sustainable Development Index Measurement Results}

The value of the sustainable development index obtained by each province shows a significant difference, which is shown in table 1.

Table 1. Human Development Index (HDI), Environmental Quality Index (EQI), Indonesian Democracy Index (IDI) and Sustainable Development Index (SDI) in 2019 


\begin{tabular}{|c|c|c|c|c|c|c|c|c|}
\hline \multirow{2}{*}{ PROVINCE } & \multicolumn{6}{|c|}{ Sustainable Development Indicator } & \multirow{2}{*}{ SDI } & \multirow{2}{*}{ Rank } \\
\hline & HDI & Rank & EQI & Rank & IDI & Rank & & \\
\hline Aceh & 71,90 & 11 & 76,12 & 7 & 78 & 10 & 89,31 & 2 \\
\hline Sumatera Utara & 71,74 & 12 & 62,49 & 22 & 67,65 & 30 & 80,85 & 29 \\
\hline Sumatera Barat & 72,39 & 9 & 69,64 & 12 & 67,69 & 29 & 83,74 & 19 \\
\hline Riau & 73,00 & 6 & 62,47 & 23 & 75,21 & 21 & 84,03 & 18 \\
\hline Jambi & 71,26 & 17 & 68,06 & 13 & 69,76 & 26 & 83,32 & 23 \\
\hline Sumatera Selatan & 70,02 & 14 & 61,41 & 25 & 78,96 & 8 & 83,45 & 21 \\
\hline Bengkulu & 71,21 & 18 & 64,41 & 20 & 78,79 & 9 & 85,06 & 11 \\
\hline Lampung & 69,57 & 23 & 57,37 & 28 & 72,56 & 23 & 79,61 & 30 \\
\hline Kep. Bangka Belitung & 71,30 & 16 & 64,85 & 18 & 76,75 & 18 & 84,57 & 16 \\
\hline Kep. Riau & 75,48 & 4 & 67,00 & 15 & 81,64 & 2 & 89,07 & 3 \\
\hline DKI Jakarta & 80,76 & 1 & 42,84 & 33 & 88,29 & 1 & 85,31 & 10 \\
\hline Jawa Barat & 72,03 & 10 & 51,64 & 29 & 69,09 & 27 & 77,60 & 33 \\
\hline Jawa Tengah & 71,73 & 13 & 60,97 & 26 & 77,22 & 16 & 83,55 & 20 \\
\hline DI Yogyakarta & 79,99 & 2 & 49,24 & 31 & 80,67 & 6 & 84,62 & 14 \\
\hline Jawa Timur & 71,50 & 15 & 60,25 & 27 & 77,68 & 11 & 83,34 & 22 \\
\hline Banten & 72,44 & 8 & 51,09 & 30 & 72,6 & 22 & 78,80 & 32 \\
\hline Bali & 75,38 & 5 & 63,09 & 21 & 81,38 & 3 & 87,53 & 5 \\
\hline Nusa Tenggara Barat & 68,14 & 28 & 64,56 & 19 & 76,64 & 19 & 82,86 & 26 \\
\hline Nusa Tenggara Timur & 65,23 & 31 & 69,67 & 11 & 81,02 & 5 & 84,73 & 13 \\
\hline Kalimantan Barat & 67,65 & 29 & 65,29 & 16 & 77,66 & 13 & 83,22 & 24 \\
\hline Kalimantan Tengah & 70,91 & 20 & 47,20 & 32 & 81,16 & 4 & 79,56 & 31 \\
\hline Kalimantan Selatan & 70,72 & 21 & 61,94 & 24 & 79,47 & 7 & 84,16 & 17 \\
\hline Kalimantan Timur & 76,61 & 3 & 80,87 & 3 & 77,67 & 12 & 93,23 & 1 \\
\hline Sulawesi Utara & 72,99 & 12 & 65,15 & 17 & 77,08 & 17 & 85,62 & 9 \\
\hline Sulawesi Tengah & 69,50 & 24 & 67,61 & 14 & 77,27 & 15 & 84,84 & 12 \\
\hline Sulawesi Selatan & 71,66 & 22 & 80,23 & 4 & 70,58 & 24 & 88,14 & 4 \\
\hline Sulawesi Tenggara & 71,20 & 19 & 72,03 & 9 & 65,21 & 32 & 83,16 & 25 \\
\hline Gorontalo & 68,49 & 27 & 74,97 & 8 & 76,29 & 20 & 86,63 & 6 \\
\hline Sulawesi Barat & 65,73 & 30 & 72,03 & 10 & 77,42 & 14 & 84,60 & 15 \\
\hline Maluku & 69,45 & 25 & 79,55 & 5 & 68,22 & 28 & 86,00 & 7 \\
\hline Maluku Utara & 68,70 & 26 & 78,44 & 6 & 69,89 & 25 & 85,80 & 8 \\
\hline Papua Barat & 64,70 & 32 & 83,96 & 1 & 57,62 & 33 & 81,62 & 27 \\
\hline Papua & 60,84 & 33 & 81,79 & 2 & 65,25 & 31 & 81,53 & 28 \\
\hline Indonesia & 71,92 & & 66,55 & & 71,92 & & 70,309 & \\
\hline
\end{tabular}

Source: BPS, Processed

Table 1 provides an overview of the comparison of sustainable development achievements (SDGs) which are the composite results of HDI, EQI and IDI indicating that regional development achievements are very varied and highly contradictory, especially the relationship between HDI and EQI achievements, while for the legal and governance fields which measured by the Indonesian Democracy Index (IDI) tends to be more consistent with the HDI in several provinces, which means that a province with a high HDI tends to have better governance and law as shown by a high IDI. However, this condition implies that the governance and laws carried out by the government still tend to focus on improving the quality of human development by ignoring environmental factors. This result reinforces the development paradox that high economic and social development achievements are managed well by the government, but often have to be paid for with environmental damage because the government has not been optimal in environmental management and is still weak in law enforcement related to environmental pollution or destruction. There are still many parties who are free to explore natural resources which are actually protected by law because of their interest in increasing regional income. 


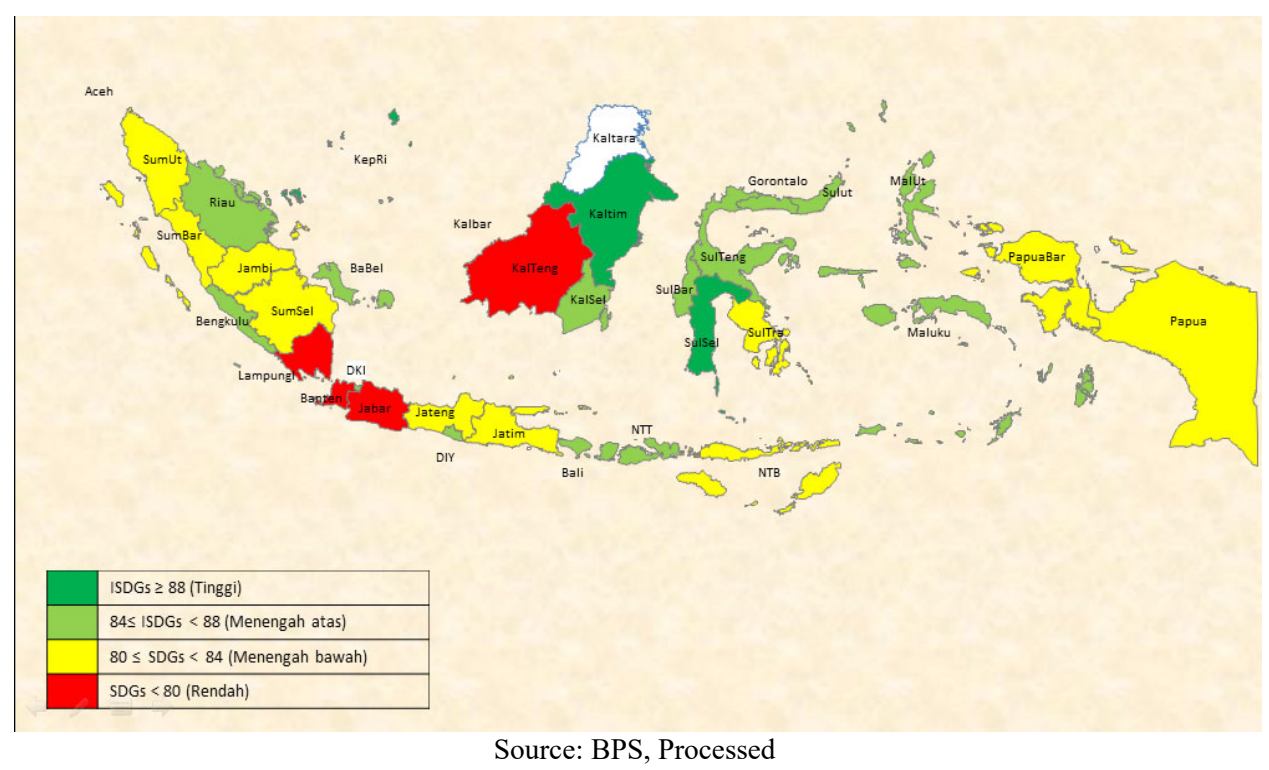

Fig. 3. Distribution Map of Sustainable Development Achievements Indonesia in 2019

Based on the calculation of the Sustainable Development Index using a composite index consisting of HDI, EQI and IDI, the results show that the Province that received the highest sustainable Development index score in 2019 was the province of East Kalimantan with a score of 93.23, the second position was the Province of Aceh Darusallam with a score of 89 , 13 and the third position is the Riau Islands with a score of 89.07. East Kalimantan occupies the first position of SDI because it has high values for HDI, EQI and IDI. In 2019, the three provinces with the lowest SDI value were West Java with an SDI value of 77.60, Banten with an SDI value of 78.80 and Central Kalimantan with an SDI value of 79.56. West Java Province is an interesting province to discuss in achieving sustainable development because it is the area closest to the center of the national government, but it has the lowest human resources in Indonesia, although in terms of development the human quality is quite high, West Java is the province with the highest number of human resources. Owning a manufacturing industry turns out to have very low EQI and IDI values so that they are ranked 29 and 27 out of 33 provinces in Indonesia, which means that environmental development and governance in West Java do not support the achievement of sustainable development.

In several references it is stated that the development that has been carried out so far has focused more on the island of Java, but in terms of sustainable development in reality almost half of the areas on the island of Java actually do not show low sustainable development achievements, such as in West Java, Banten, East Java and Central Java shown in red on the map. The low value of SDI in the provinces on the island of Java is due to the very low EQI value which means that environmental development on the island of Java is not given enough attention, the government only pursues an increase in Gross Regional Domestic Income to increase HDI, but ignores environmental development, this condition is exacerbated by good governance. which is not good in Java, which is shown by the low IDI score. Below is a 
description of the distribution of SDI's achievements in Indonesia which shows quite varied differences.

\subsection{Panel Data Model Analysis Results}

The Sustainable Development Index in Indonesia will be estimated using the panel data regression method with independent variables consisting of local government spending, the ratio of local taxes to GRDP (Tax Ratio), inflation, and the level of effectiveness of regional financial management are variables that represent the role of the government, while for the role of the private sector, it is measured by the amount of bank credit per province and the amount of private investment, then the performance of Micro and Small Enterprises (SMEs) to represent the behavior of the community in society with a productive workforce and the variable Gross Enrollment Rate (GER) of universities. Before making an estimate, first determine the appropriate panel data regression model as an estimation method.

Table 2. Estimating Common Effect Model, Fixed Effect Model and Random Effect Model

\begin{tabular}{clllllc}
\hline \multirow{2}{*}{ Variable } & \multicolumn{2}{c}{ CEM } & \multicolumn{2}{c}{ FEM } & \multicolumn{2}{c}{ REM } \\
\cline { 2 - 7 } & Coefficient & $\boldsymbol{P}$-value & Coefficient & $\boldsymbol{P}$-value & Coefficient & P-value \\
\hline GOV & $-0,079380$ & 0,2081 & $-0,057602$ & 0,1424 & $-0,0418$ & 0,2019 \\
TR & 0,415187 & 0,1671 & 0,115469 & 0,5263 & 0,15090 & 0,3635 \\
INF & 0,658861 & 0,0863 & $-0,102439$ & 0,5433 & $-0,1082$ & 0,5080 \\
CREDIT & $-0,048892$ & 0,5665 & $-0,575157$ & 0,4289 & $-0,2006$ & $0,0229^{*}$ \\
INV & 0,201939 & 0,0039 & $-0,030991$ & 0,6418 & 0,01024 & 0,8404 \\
SMEs & 0,049710 & 0,0000 & 0,006837 & 0,2894 & 0,01026 & $0,0829^{* *}$ \\
GER & 0,203149 & 0,0000 & 0,187841 & 0,0972 & 0,12591 & $0,0036^{*}$ \\
EF & 0,203149 & 0,0000 & $-0,015652$ & 0,7120 & $-0,0248$ & 0,5176 \\
C & \multicolumn{7}{c}{82,37945} & 0,0000 & 82,1324 & 0,0000 \\
R ${ }^{2}$ & 0,53 & 0.70 & & & 0.83 \\
\hline
\end{tabular}

Testing the selection of the best model begins with the Chow Test which is a test to see which method is the most appropriate to use between CEM and FEM. Calculation of the Chow test for SGDs Index data in Indonesia obtained Fcount $=0.00$ and p-value $=0.00$ which is less than $=0.05$ then the decision rejects $\mathrm{H} 0$ or it can be concluded that there is an individual effect on the Indonesian SDGs Index equation model, so the appropriate model is the FEM model.

Table 3. Chow Test Result

\begin{tabular}{lcrc}
\hline \multicolumn{1}{c}{ Effects Test } & Statistic & d.f. & Prob. \\
\hline Cross-section F & 6.559955 & $(32,90)$ & 0.0000 \\
Cross-section Chi-square & 157.684877 & 32 & 0.0000 \\
\hline \multicolumn{4}{c}{ Source : Proceesed Result }
\end{tabular}

Then the Hausman test was carried out to determine which method was the most appropriate between REM and FEM. Based on table 4 shows the prob value. The chi-squares for the estimated result of the Hausman test is 0.8028 , because the value of Prob. chi-square is more than 0.05 , it can be concluded that $\mathrm{H} 1$ is rejected, which means. The regression estimation used is the estimation of the Random effect model. 
Table 4. HausmanTest Result

\begin{tabular}{cccc}
\hline Test Summary & Chi-Sq. Statistic & Chi-Sq. d.f. & Prob. \\
\hline Cross-section random & 4.566323 & 8 & 0.8028 \\
\hline \multicolumn{4}{c}{ Source : Proceesed Result }
\end{tabular}

After testing the two models above, it can be concluded that the F test (Chow test) determines FEM, but the Hausman test shows that the REM is selected so that overall it can be said that the most appropriate estimate is the Random effect model.

Table 5. Random Effect Estimation Results on the Sustainable Development Equation

\begin{tabular}{lrrrr}
\hline \multicolumn{1}{c}{ Variable } & Coefficient & Std. Error & t-Statistic & \multicolumn{1}{c}{ Prob. } \\
\hline C & 82.13241 & 4.231126 & 19.41148 & 0.0000 \\
GOV? & -0.041860 & 0.032627 & -1.282998 & 0.2019 \\
TR? & 0.150905 & 0.165458 & 0.912044 & 0.3635 \\
INF? & -0.108239 & 0.163033 & -0.663905 & 0.5080 \\
CREDIT? & -0.200661 & 0.087064 & -2.304737 & 0.0229 \\
INV? & 0.010240 & 0.050736 & 0.201824 & 0.8404 \\
SMEs? & 0.010268 & 0.005873 & 1.748347 & 0.0829 \\
GER? & 0.125915 & 0.042392 & 2.970224 & 0.0036 \\
EF? & -0.024838 & 0.038280 & -0.648862 & 0.5176 \\
R-squared & 0.819831 & Mean dependent var & 29.73969 \\
Adjusted R-squared & 0.830427 & S.D. dependent var & 2.054503 \\
S.E. of regression & 1.889155 & Sum squared resid & 435.4068 \\
F-statistic & 2.479077 & Durbin-Watson stat & 1.497174 \\
Prob(F-statistic) & 0.015855 & & & \\
\hline
\end{tabular}

Source : Proceesed Result

The next step is to estimate the model based on the estimation results using the REM approach as presented in table 5. Then the equation model for the Indonesian Sustainable Index is obtained as follows:

$$
\begin{aligned}
\mathrm{SDI}_{\mathrm{it}}= & 82.13241-0.04186 . \mathrm{GOV}_{\mathrm{it}}+0.15090 . \mathrm{TR}_{\mathrm{it}}-0.10823 . \mathrm{INF}_{\mathrm{it}}-0.02483 . \mathrm{EF}_{\mathrm{it}}+0.01024 . \\
& \mathrm{INV}_{\mathrm{it}}-0.20066 . \mathrm{CREDIT}_{\mathrm{it}}+0.12591 . \mathrm{GER}_{\mathrm{it}}+0.01026 . \mathrm{SMES}_{\mathrm{it}}+\varepsilon_{\mathrm{it}}
\end{aligned}
$$

Based on the estimation results of the sustainable development equation model, the result is that the constant value in the equation is 82.13241, which means that if all the independent variables used in the study are 0, then the SDGs index in Indonesia is 82.13241. The results of the $t$ test show that the independent variables that significantly affect the SDGs index are the amount of bank credit, the performance of micro and small businesses and the gross enrollment rate of higher education because each has a p-value of less than 0.05 . The coefficient value for bank credit is significant but has a negative direction of -0.200661 which means that if banking credit for micro and small businesses increases, it will decrease the sustainable development index (SDI). This bank credit is a form of the role of the private sector in financing the achievement of sustainable development through the banking sector. The direction of the negative coefficient indicates that credit disbursed by the private sector has not been utilized optimally for more productive activities but is still mostly used for consumptive needs so that it has little effect on people's income so that it is not optimal in achieving the SDGs.

Community participation in society is very much needed in achieving sustainable development, especially to improve the welfare of the lower middle class community 
through the empowerment of Micro and Small Enterprises. This condition is in accordance with the estimation results which show that the coefficient value on the performance of Micro and Small Enterprises (SMEs) has a positive and significant direction towards the SDGs index of 0.010268, which means that if the performance of Micro and Small Enterprises increases by 1 percent, it will affect the increase in the SDI index of 0.010268 points. . The last variable that significantly affects the sustainable development index is the role of academics, especially at the tertiary level, which is an important party in improving the quality of human resources as the main source of driving sustainable development. This result is shown by the GER value of higher education which has a significant coefficient and has a positive direction with a coefficient value of 0.125915 , which means that if the GER of higher education has an increase of 1 percent, the SDI will increase by 0.125915 points. The increasing enrollment rate for higher education (GER) shows that services for access to educators are getting higher, especially for higher education levels. The conditions are in accordance with the increasing number of private private universities in various fields of science in various provinces in Indonesia. Based on the estimation results above, it is obtained that the variables that represent the government's role in financing and improving services for sustainable development achievements show insignificant results.

\section{Conclusions}

The conclusions that can be summarized in this study are as follows :

1. The ratio of tax revenue to GRDP (Tax Ratio) has no significant effect on the Sustainable Development Index (SDI)

2. Local government spending does not significantly affect the Sustainable Development Index (SDI) in Indonesia

3. The level of effectiveness of regional financial management has a positive effect on the Sustainable Development Index (SDI)

4. Inflation rate has no effect on the Sustainable Development Index (SDI)

5. Bank credit significantly affects SDI but in a negative direction which indicates that many bank loans are still consumptive in nature, not being utilized for productive purposes.

6. Private investment has no effect on the Sustainable Development Index (SDI)

7. The Gross Enrollment Rate (GER) of Higher Education has a significant effect and has a positive direction on the Sustainable Development Index (SDI)

8. The performance of Micro and Small Enterprises has a significant and positive direction on the Sustainable Development index (SDI)

\section{Suggestion}

The estimation results in this study did not show the expected results, because many independent variables from the results of hypothesis testing showed that they were not significant to the achievement of sustainable development or the SDGs index shown that did not pass the t-test. can replace the variables that indicate the government's role in sustainable development to be included in the equation of the sustainable development model, such as infrastructure, the level of efficiency of financial management and various fiscal and monetary policies that are able to encourage the achievement of sustainable development. 


\section{References}

[1] A. Fauzi dan A. Oxtavianus, "Pengukuran pembangunan berkelanjutan di Indonesia," Mimb. J. Sos. dan Pembang., vol. 30, no. 1, hal. 42-52, 2014.

[2] M. Nourry, "Measuring sustainable development: Some empirical evidence for France from eight alternative indicators," Ecol. Econ., vol. 67, no. 3, hal. 441-456, 2008.

[3] J. Kondyli, "Measurement and evaluation of sustainable development: A composite indicator for the islands of the North Aegean region, Greece," Environ. Impact Assess. Rev., vol. 30, no. 6, hal. 347-356, 2010.

[4] H. Phimpanthavong, "The Determinants of Sustainable Development in Laos," Int. J. Acad. Res. Manag., vol. 3, no. 1, hal. 2014, 2014.

[5] Bappenas, "Sustainable Development Index Preparation Study." Bapennas, Jakarta, 2007.

[6] K. Wibowo, Sustainable Development Index Preparation Study. Jakarta: BPPT, 2009. 